\title{
İzmir Kalkınma Ajansı Örneğinde Kalkınma Kurulu'nun Yönetişim Yaklaşımı ile Analizi
}

\author{
Fatih Çelik ${ }^{*}$
}

Milli Eğitim Bakanlığı, Yenifakılı Çok Programlı Anadolu Lisesi, Yozgat

\begin{abstract}
$\ddot{O} z$
Bölgesel Kalkınma Ajansları, bölgesel kalkınmaya katkıda bulunmak üzere 1930'lardan itibaren kurulan örgütlerdir. Bölgesel kalkınmaya yönelik stratejiler geliştirmiş ve uygulamıştır. "Aşă̆ıdan yukarıya" doğru örgütlenme modeline göre kurulmuştur. Bu model, merkezi yönetimin yetki ve sorumluluklarını bir kısminin yerel aktörlere deoredilmesine dayanmaktadır. $\mathrm{Bu}$ yetki transferi, yönetimden yönetişime geçiş olarak nitelendirilir. Bölgesel Kalkınma Ajansları'nda uygulanan yönetişim yaklaşımı, sermaye kesimini öne çıkarmak ve işçi kesimini dışlamak gibi siyasi; bölgesel refahı toplumsal kesimler arasında eşitsiz dağıtmak gibi ekonomik; sosyal kalkınmayı ihmal etmek gibi sosyal nedenlerle eleştirilmiştir. Türkiye'de Bölgesel Kalkınma Ajansları, 2006 yılından itibaren kurulmaya başlanmıştır. Yönetim Kurulu, Kalkınma Kurulu, Genel Sekreterlik ve Yatırım Destek Ofisi şeklinde örgütlenmiştir. Bölgesel Kalkınma Ajansları'nda yönetişim yaklaşımı öncelikle yerel aktörlerden oluşan Kalkınma Kurulu'nda uygulanmıştır. Araştırmanın amacı, Türkiye'deki Bölgesel Kalkınma Ajansları'ndan İzmir Kalkınma Ajansı Kalkınma Kurulu'nun oluşum ve işleyiş sürecini yönetişim yaklaşımı ile analiz etmektir. Konu, nitel araştırma yöntemlerinden doküman analizi tekniği ile incelenmiştir. Analiz sonucunda İzmir Kalkınma Ajansı'nın, Kalkınma Kurulu üyelerinin kamu, özel ve sivil kesimler itibariyle dağılımı ile kurulda oluşturulan çalışma grubu ve komitesi bakımından yönetişim yaklaşımını tam olarak; üyelerin toplantılara katılımı itibariyle de kısmen uyguladığına kanaat getirilmiştir.
\end{abstract}

Anahtar Kelimeler: Bölgesel Kalkınma Ajansl, Yönetişim, İzmir Kalkınma Ajansı, Kalkınma Kurulu, Kamu-Özel-Sivil Kesim.

\section{The Analysis of The Development Board with Governance Approach in the Case of Izmir Development Agency}

\begin{abstract}
Regional Development Agencies are organizations established to contribute to regional development since 1930. They developed and implemented strategies for regional development. They were established according to the right-to-up organization model. This model is based on the transfer of some of powers and responsibilities of central government to local actors. This transfer of authority is defined as transition from management to governance. The governance approach implemented in Regional Development Agencies has been criticized with these reasons political such as to highlighting the capital segment and to excluding the workers; economical as not not to distribute regional welfare among the social segments; and social such as neglecting the social development. Regional Development Agencies in Turkey have been established since 2006. They have been organized in the form of Development Board, the Secretariat General and the Investment Support Office. In Regional Development Agencies governance approach was first applied to the Development Board which is composed of local actors. The purpose of the study Regional Development Agencies in Turkey Izmir Development Agency Development Board is to analyze the process of formation and functioning with the governance approach. The subject was examined by qualitative research methods using document analysis technique. As a result of the
\end{abstract}


analysis Izmir Development Agency's approach to the governance in terms of the distribution of the members of the Development Board in terms of public, private and civil sectors and the working group and the working committee formed in the committee are as follows; it was also considered that the members were partially applying for participation in the meeting.

Keywords: Regional Development Agency, Governance, Izmir Development Agency, Development Board, Public-Private-Civil Sector.

\section{GíRiş}

Yerel $^{1}$ kalkınmanın aktörlerden biri, Bölgesel Kalkınma Ajansları'dır (BKA'lar). BKA'lar, merkezi ve/veya yerel aktörler tarafından kurulmaktadır. Başlıca amacı, yerel kalkınmada aktörler arasında işbirliğini (yönetişim) geliştirmektir. Yönetimi, "çok düzeyli yönetişim modeli”ne dayanmaktadır (Dulupçu, 2006: 244-245). Dolayısıyla amaçlarına ulaşma düzeyi, yönetişim yaklaşımını ne ölçüde uyguladığına bağlıdır.

Türkiye'de 5449 sayılı kanuna göre 2006-2009 y1lları arasında 26 tane BKA² kurulmuştur. BKA'lar, Yönetim Kurulu, Kalkınma Kurulu, Genel Sekreterlik ve Yatırım Destek Ofisi şeklinde örgütlenmiştir. BKA'larda yönetişim yaklaşımı öncelikle Kalkınma Kurulu'nun oluşum sürecinde uygulanmıştır. 5449 sayılı kanuna (md. 8) göre, “... bölgedeki kamu kurum ve kuruluşları, özel kesim, sivil toplum kuruluşları, üniversiteler ve yerel yönetimler arasında işbirliğini geliştirmek ve ajansı yönlendirmek üzere kalkınma kurulu oluşturulur. İllerin dengeli şekilde temsilini sağlayacak yapıda, en fazla yüz üyeden ${ }^{3}$ oluşur.".

Çalışmada Türkiye'deki BKA'lardan İzmir Kalkınma Ajansı (İZKA) Kalkınma Kurulu'nun (KK) oluşum ve işleyiş süreci, yönetişim yaklaşımı ${ }^{4}$ ile incelenmiştir. Analizde, yönetişim yaklaşımını ideolojik yönden sorgulamadan, kanunla yönetişim temelinde oluşturulan bir örgütsel yapının uygulamada yönetişimi ne ölçüde gerçekleştirdiği irdelenmiştir. Çalışmanın temel önermesi, Türkiye'de BKA'ların yönetişim modelini uygulamada tam olarak içselleştiremediğidir.

Çalışma, beş bölümden oluşmuştur. İlk olarak, yönetişim yaklaşımı ve BKA'lar kısaca ele alınmıştır. Daha sonra BKA'larda yönetişime ve İKA'ya ilişkin literatüre yer verilmiştir. Üçüncü bölümde, IZZKA KK, üyelerin kamu-özel-sivil kesim itibariyle dağılımı, toplantılara katılım durumu ve kurulda oluşturulan çalışma grubu ve komitesi bakımından yönetişim yaklaşımı ile analiz edilmiştir. Dördüncü bölümde, araştırmanın amacı, yöntemi, sınırları ve sınırlılığı belirtilmiştir. Son olarak, araştırmanın bulguları ortaya konmuştur.

\footnotetext{
${ }^{1}$ Çalışmada yerel ve bölgesel kavramları, aynı anlamda kullanılmıştır.

2 Türkiye'de ajanslar, dünyada yaygın olan BKA yerine "bölge" kelimesi çıkarılarak Kalkınma Ajansı (KA) şeklinde adlandırılmıştır. Bunun başlıca nedeni, "bölge" kelimesinin bölge yönetiminden başlayarak eyalet sistemine doğru bir yönetim şeklini getireceği endişesidir. Çalışmada, BKA kavramı kullanılmıştır. ${ }^{3}$ Kalkınma Bakanlığı'nın 07.06.2017 tarih ve 2646 sayılı yazısında, tek ilden oluşan bölgelerde (İstanbul, Ankara ve İzmir) KK'nın en fazla 25 üyeden oluşacağı belirtilmiştir. Bu durumun, KK'nın yönetişim yapısını zayıflatacağı söylenebilir.

${ }^{4}$ Literatürde, birden fazla ili kapsayan ajanslar için "bölgesel yönetişim"; İstanbul, İzmir ve Ankara'da kurulan ajanslar için de “kentsel yönetişim” ayırımı yapılmıştır (ÖZışık, 2012: 132).
} 


\section{KAVRAMSAL ÇERÇEVE}

Bu bölümde, yönetişim yaklaşımı ve BKA kavramları kısaca ele alınmıştır.

\subsection{Yönetişim Yaklaşımı}

1980'li yıllarda başlayan küreselleşme süreci ile ulusal kalkınma anlayışının yerini 1990’larda bölgesel kalkınma anlayışı almıştır. Küreselleşme, “bilişim teknolojilerindeki gelişmeler sonucunda ulus devletlerin ekonomik, siyasi ve idari alandaki rolünün azaldığı, bölgelerin öne çıtığı bir süreç"tir (Dinler, 2008: 402). Küreselleşmenin etkilerinden biri, ülkeleri yönetimden yönetişime geçişe zorlamasıdır. Washington Uzlaşması (1986) ile küresel sermayenin aktörleri olan ulus-üstü kurumlar ${ }^{5}$, ülkelere ticari serbestleşme, âdemi merkezileşme ve yönetişim modelini benimsetmek için hemfikir olmuşlar (Müftüoğlu, 2012: 98; Özışık, 2012: 130).

Yönetişim modeli, merkezi yönetimin bazı yetki ve sorumluluklarının yerel aktörlere devredilmesine dayanır. Âdem-i merkezileşme (yerelleşme) olarak da adlandırılan bu süreç, "yönetim"den "yönetişim"e geçiş olarak nitelendirilmiştir (Dulupçu, 2006: 244-245; Eraydın, 2007: 9). Bu modele göre merkezi yönetim, "yönetme" görevinin yerine "yönlendirme" rolünü üstlenmiştir.

Yönetişim, kısaca kamu, özel ve sivil aktörlerin işbirliği yapmasıdır. Bu modelde herhangi bir aktör, karar verme sürecine egemen değildir (Dulupçu, 2006: 244-245). Model, iki temel özelliğe sahiptir. İlki, katılımcılıktır. Yani yetki ve sorumlulukların aktörler arasında paylaşılmasıdır. İkincisi ise, hiyerarşik yapıdan eşitler arası ilişkilere dayalı bir heterarşik yapının kurulmasıdır (Eraydın, 2007: 11-12).

Yönetişim modelinde, Marks ve Hooghe'ın (2004) geliştirdiği tipoloji, başlica kaynaklardan biridir. Bu yazarlar, modeli Tip 1 ve Tip 2 yönetişim modeli şeklinde iki gruba ayırmıştır. Tip 1'de yetki dağılımı, coğrafi olarak sınırlandırılmıştır. Tip 2' de ise, mekân ve aktörler bakımından yetki sınırlaması yoktur. Yönetişim, tüm aktörlerin katılımı ile çok düzeyli bir şekilde sağlanır (Helvacıoğlu ve Tektaş, 2010: 530).

\subsection{Bölgesel Kalkınma Ajansı}

Yerel kalkınmayı hızlandırmak ve aktörler arasında işbirliğini geliştirmek üzere 1930'lardan itibaren Bölgesel Kalkınma Ajansları (BKA'lar) kurulmaya başlanmıştır. BKA'ların başlıca faaliyetleri, kalkınma stratejilerini hazırlamak, aktörler arasında işbirliğini geliştirmek ve kalkınma fonlarını yönetmektir. Genel kurul, yönetim kurulu, denetleme komitesi şeklinde örgütlenmiştir (EURADA, 1999: 34).

Örgütlenme bakımından ideal bir BKA, Halkier et al., (1998) ile Halkier'e (2000: 42; 2010: 29; 2011) göre, aşağ1dan yukarıya doğru yapılanmıştır ve merkezi yönetimden yarı özerk, çok işlevli bir kurumdur. Bu özerklik ve yapılanma, BKA'lara aktörler arasında aracılık rolünü vermiştir (Roberts and Lloyd, 1999: 519-520).

BKA'lar için ortak bir örgütlenme modeli yoktur (Harding, 2006: 137-138). Avrupa'daki BKA'ların kurumsal yapıları, Tablo 1'de sunulmuştur.

\footnotetext{
${ }^{5}$ Uluslararası Para Fonu, Dünya Bankası, Dünya Ticaret Örgütü, Ekonomik Kalkınma ve İşbirliği Örgütü.
} 
Tablo 1. Avrupa'daki BKA'ların Kurumsal Yapıları

\begin{tabular}{|l|l|}
\hline Ülkeler & BKA'ların Kurumsal Yapısı \\
\hline İspanya, Türkiye & Özel hukuka tabi kamu kurumu \\
\hline Almanya & Yarı özerk kamu şirketi \\
\hline Fransa & Karma ekonomi şirketi \\
\hline Belçika & Belediyeler arası ajanslar \\
\hline Romanya, Danimarka & Vakıflar \\
\hline İsveç & Limited şirket \\
\hline İngiltere & Özerk örgüt \\
\hline Yunanistan & Belediye girişimi \\
\hline Çek Cum., Estonya, Slovakya, Polonya & Kamu-özel sektör şirketi \\
\hline
\end{tabular}

Kaynak: EURADA, 1999: 33'den yararlanılarak hazırlanmıştır.

Tablo 1'de de görüldüğü gibi, kurumsal yapıları bakımından tek tip BKA yoktur. Bunun başlica nedeni, ülkelerin politik tercihleridir. BKA'lar, özel hukuka tâbi olarak merkezi ve/veya yerel yönetimler tarafından özerk ve/veya yarı-özerk örgütler şeklinde kurulmuştur. Kimi ülkelerde vakıf, şirket, kamu-özel sektör ortaklı̆̆1 gibi çeşitli statülere sahiptir. BKA'ların amaçlarını gerçekleştirebilmeleri için merkezden belli oranda özerkliğe sahip olmaları, ortak bir özelliktir (Young-Hyman, 2008: 380).

BKA'ların başlıca amacı, aktörler arasında işbirliğini (yönetişim) geliştirmektir. Merkezi ve/veya yerel aktörler tarafından "çok düzeyli yönetişim modeli"ne göre kurulmuştur (Halkier, 2006: 23-24). Bu durum çeşitli yönlerden eleştirilmiştir. BKA'larda yönetişim modelinin tam olarak kurulamadığı; merkezi yönetimin, yönetim kuruluna kendine yakın kesimleri atadığı; kurula, yerel aktörlerden ziyade iş dünyasının temsilcilerinin seçildiği; dolayısıyla yönetişim yapısının, toplumu temsil etme bakımından sorunlu olduğu belirtilmiştir (Kayasü et al., 2003: 43).

BKA'ların yönetiminde, kamu ve sermaye kesimlerinin öne çıktığ1; bunun da arz temelli politikaları ve sermayenin egemenliğini pekiştirdiği ileri sürülmüşsür ${ }^{6}$. Bu durum, "örgütlü sermaye"nin BKA'larda temsil edilirken; çoğunluğu oluşturan “örgütsüz kesim”in ve işçi sendikalarının dışlanmasının bir sonucudur (Karasu, 2009: 23). Bu sonuç, eşitsiz güç ilişkilerinin bir göstergesi olarak kabul edilir. Yerel elitlerin daha fazla güç sağlama çabası, hiyerarşik yapılanmaya ve güçlü bölgelerin yatırımları belirlemesine yol açmıştır. Dolayısıyla yönetişim mekanizması, "elit oyun alanları" olarak adlandırılmıştır (Müftüoğlu, 2006: 138; Müftüoğlu, 2012: 99-100).

\section{LİTERATÜR ÖZETI}

BKA'lar, literatürde yönetişim yaklaşımı ile daha ziyade örgütsel yapıları ve aktörler arasında işbirliğini geliştirme faaliyetleriyle incelenmiştir. Bu bölümde literatür özeti, yabancı ve yerli kaynaklar şeklinde iki tabloda verilmiştir. BKA'ların yönetişim modeli ile ilgili yabancı literatür özeti, Tablo 2'de sunulmuştur.

\footnotetext{
${ }^{6} \mathrm{Bu}$ bakımdan yönetişim, siyasal iktidarın kimler tarafından kullanılacağına yönelik mekanizmaları oluşturan yeni bir iktidar yaklaşımı olarak değerlendirilmiştir.
} 
Tablo 2. BKA'ların Yönetişim Yaklaşımı İle İncelendiği Başlıca Çalışmalar* (Özet)

\begin{tabular}{|c|c|c|c|}
\hline Yazarı & Amaci & Yöntemi** & Sonucu \\
\hline $\begin{array}{l}\text { Beer et } \\
\text { al. } \\
(2004)\end{array}$ & $\begin{array}{l}\text { Avustralya, İngiltere, ABD ve } \\
\text { Kuzey İrlanda'nın bölgesel } \\
\text { kalkınma deneyimlerini ortaya } \\
\text { koymaktır. }\end{array}$ & Anket & $\begin{array}{l}\text { BKA'lar, işletmelerle diğer } \\
\text { kurumlar arasında güçlü ağ } \\
\text { ilişkileri kurmuştur. }\end{array}$ \\
\hline $\begin{array}{l}\text { Grant } \\
(2004)\end{array}$ & $\begin{array}{l}\text { Sosyal sermaye, bölgesel } \\
\text { yönetişim ve kültür } \\
\text { unsurlarının, Avustralya'da iki } \\
\text { iki BKA'nın faaliyetlerine } \\
\text { etkisini incelemektir. }\end{array}$ & $\begin{array}{c}\text { Anket, } \\
\text { Mülakat }\end{array}$ & $\begin{array}{l}\text { Yönetişim konusunda kamu } \\
\text { kaynakları, toplumsal veya } \\
\text { ekonomik kazançlar yerine politik } \\
\text { amaçlarla istismar edilmiştir. }\end{array}$ \\
\hline $\begin{array}{c}\text { Halkier } \\
(2006)\end{array}$ & $\begin{array}{l}\text { Avrupa'daki BKA'ların başlıca } \\
\text { özeliklerini, farklılıklarını ve } \\
\begin{array}{l}\text { gelişme eğilimlerini ele } \\
\text { almaktır. }\end{array}\end{array}$ & $\begin{array}{l}\text { Doküman } \\
\text { Analizi }\end{array}$ & $\begin{array}{l}\text { Kalkınma yapılarının \% } 80^{\prime} \mathrm{i} \\
\text { politik otoriteden bağımsız olan } \\
\text { BKA'lar, daha başarılıdır. }\end{array}$ \\
\hline $\begin{array}{c}\text { Halkier } \\
(2010)\end{array}$ & $\begin{array}{lr}\text { BKA'lar } & \text { temelinde } \\
\text { Avrupa'daki } & \text { bölgesel } \\
\text { kalkınma } & \text { politikaların } \\
\text { incelemektir. } & \\
\end{array}$ & Anket & $\begin{array}{l}\text { Yönetişim bakımından anketin } \\
\text { başlıca bulgusu, BKA'ların ağ } \\
\text { ortamında faaliyet gösterdiğidir. }\end{array}$ \\
\hline $\begin{array}{c}\text { Halkier } \\
(2011)\end{array}$ & 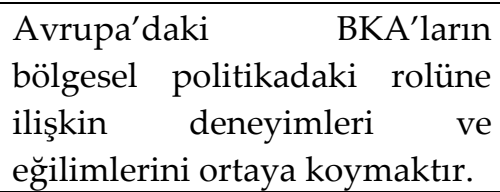 & $\begin{array}{c}\text { Doküman } \\
\text { Analizi }\end{array}$ & $\begin{array}{l}\text { BKA'lar, çok düzeyli bir } \\
\text { yönetişim yapısına sahiptir. }\end{array}$ \\
\hline $\begin{array}{l}\text { Dall'Oli } \\
\text { o (2006) }\end{array}$ & $\begin{array}{l}\text { ERVET'in kuruluşu, gelişimi } \\
\text { ve değişen misyonunu } \\
\text { incelemektir. }\end{array}$ & $\begin{array}{l}\text { Vaka } \\
\text { Analizi }\end{array}$ & $\begin{array}{l}\text { Bölgesel planlamada ERVET, } \\
\text { yeniden yapılanmıştır. }\end{array}$ \\
\hline $\begin{array}{l}\text { Roberts } \\
(1999)\end{array}$ & $\begin{array}{lr}\text { İngiltere'de bölgesel planlama, } \\
\text { kalkınma ve } \quad \text { yönetim } \\
\text { anlayışındaki } & \text { değişimi } \\
\text { incelemektir. } & \end{array}$ & $\begin{array}{l}\text { Doküman } \\
\text { Analizi }\end{array}$ & $\begin{array}{l}\text { BKA'ların üç temel rolü vardır. } \\
\text { Bunlar, bölgesel planlama ve } \\
\text { yönetim ile bölgeye özgü } \\
\text { kalkınma. }\end{array}$ \\
\hline $\begin{array}{l}\text { Morris } \\
(2010)\end{array}$ & $\begin{array}{lr}\text { İngiltere'deki } & \text { BKA'lar } \\
\text { temelinde } & \text { ekonomik } \\
\text { kalkınmada çok } & \text { sektörlü } \\
\text { işbirliğini araştırmaktır. }\end{array}$ & Mülakat & $\begin{array}{l}\text { Bölgesel kalkınmada çok sektörlü } \\
\text { işbirliğini etkileyen } 13 \text { faktörden } \\
\text { biri, yönetişimdir. }\end{array}$ \\
\hline $\begin{array}{l}\text { Gibbs } \\
\text { ve Jonas } \\
\text { (2001) }\end{array}$ & $\begin{array}{l}\text { İngiltere'de BKA'ların bölgesel } \\
\text { yönetişimde yol açacağı } \\
\text { değişikliği ele almaktır. }\end{array}$ & $\begin{array}{l}\text { Doküman } \\
\text { Analizi }\end{array}$ & $\begin{array}{l}\text { BKA'ların çevre politikası ve } \\
\text { sürdürülebilir kalkınmadaki rolü } \\
\text { belirsizdir. }\end{array}$ \\
\hline $\begin{array}{l}\text { Pearce } \\
\text { ve } \\
\text { Ayres } \\
(2009)\end{array}$ & $\begin{array}{lr}\text { İngiltere'de } & \text { BKA'ların } \\
\text { rollerini, } & \text { kaynaklarını, } \\
\text { başarılarını, önceliklerle ilgili } \\
\text { zorluklarını incelemektir. }\end{array}$ & $\begin{array}{l}\text { Doküman } \\
\text { Analizi, } \\
\text { Mülakat }\end{array}$ & $\begin{array}{l}\text { BKA'lar, ekonomik farklılıklar } \\
\text { üzerinde önemli bir etki yaratacak } \\
\text { yeterli kaynağa sahip değildir. }\end{array}$ \\
\hline
\end{tabular}

*Çalışmalar, BKA'larda yönetişim ile ilgili olanlar arasından seçilmiştir.

**Kimi çalışmalarda, yöntem belirtilmemiştir. Bu, yazar tarafından belirlenmiştir.

Kaynak: Yazar tarafından geliştirilmiştir.

Tablo 2'ye göre BKA'ları, Beer et al. (2004), Avustralya, İngiltere, ABD ve Kuzey İlanda; Grant (2004), Avusturalya; Halkier (2006, 2010 ve 2011), Avrupa; Dall'Olio 
(2006), İtalya'daki ERVET; Roberts (1999), Gibbs ve Jonas (2001), Pearce ve Ayres (2009) ve Morris (2010), İngiltere örneklerinde çeşitli yönlerden yönetişim ile analiz etmişler.

BKA'lar, yönetişim yaklaşımı ile daha ziyade İtalya, İngiltere gibi AB ülkeleri örnekleriyle incelenmiştir. İtalya'daki BKA'ların yasal statüleri birbirinden farklıdır. BKA'lar kamu şirketi olup, merkezi yönetime bağlıdır. İtalya' daki BKA'lar arasında en çok analiz edilenlerden biri, ERVET'dir. ERVET (1973), aktörler arasında işbirliğini geliştirmesi için kurulmuştur. Örgütsel ve finansal yapısı, yönetişim temelinde gerçekleşmiştir (Cooke ve Morgan, 1995: 109). Bölge yönetiminin, bankaların ve ticaret odalarının ortak olduğu ve finanse ettiği bir holdingtir (Marzocchi, 2009: 45). Kamuözel-sivil kesimler için bir "buluşma noktası" olmuştur (Halkier, 2006: 71). Yönetim kurulu, denetçiler kurulu ve bölüm şefleri şeklinde örgütlenmiştir (Maccani, 2007: 9). “Reel Hizmet Merkezleri”nin (RSCs) ağını yönetmiştir. Pyke (1994), E-R'nin kalkınmasında başlıca unsurlar olarak "işletmeler arası işbirliği"ni ve "kurumsal altyapı desteği"ni (RSC'ler) belirtmiştir (Asheim, 1995: 9).

İngiltere, BKA'ların kurulması (1999) ve kaldırılması (2012) konusunda önemli bir deneyime sahiptir (Çelik, 2017a: 146). İngiltere'de yönetişim ilkeleri ile 9 tane BKA kurulmuştur (Harding, 2006: 146). BKA'lara, aktörler arasında işbirliğini geliştirme görevi verilmiştir (Karasu, 2005: 208-210). Londra dışındaki BKA'lar, özerk bir yapıda örgütlenmiştir (Roberts ve Lloyd, 2000: 76). Örgütsel ve personel yapıları, bölgelerin özelliklerine göre değişmiştir. Merkezi yönetimin atadığı başkan ile 15 kişilik yürütme kurulu tarafından yönetilmiştir. Kurul üyelerinin \% 60-80'i, özel sektör temsilcisidir (Allen, 2002: 13-14; Harding, 2006: 140).

Türkiye'de ise BKA'lar, genel olarak ekonomik, sosyal ve siyasal yönleriyle ele alınmıştır (Çelik, 2015: 103). Türkçe literatürde BKA'ları yönetişim modeli ile inceyen çalışmalar, Tablo 3'de sunulmuştur. 
Tablo 3. Türkiye' de BKA'ların Yönetişim Yaklaşımı İle İncelendiği Başlıca Çalışmalar* (Özet)

\begin{tabular}{|c|c|c|c|}
\hline Yazarı & Amacı & Yöntemi** & Sonucu \\
\hline $\begin{array}{l}\text { Lagendijk et } \\
\text { al. (2009) }\end{array}$ & $\begin{array}{l}\text { BKA'ların çok düzeyli } \\
\text { yönetişim sistemi içinde ne } \\
\text { derece yer alacağını } \\
\text { sorgulamaktır. }\end{array}$ & & $\begin{array}{ll}\text { BKA'ların } & \text { örgütlenmesi ve } \\
\text { kurumsal } & \text { gömülmesi için } \\
\text { daha } & \text { çok } \\
\text { gerekmektedir. }\end{array}$ \\
\hline $\begin{array}{l}\text { Karakılçık ve } \\
\text { Sarıgül (2010) }\end{array}$ & $\begin{array}{l}\text { BKA'ları ekonomik } \\
\text { yönetişim modeli ile } \\
\text { incelemektir. }\end{array}$ & $\begin{array}{l}\text { Doküman } \\
\text { Analizi }\end{array}$ & $\begin{array}{l}\text { Ulus devleti tasfiyeye } \\
\text { yönelik politikalar, BKA'larla } \\
\text { yönetişim modeli ile } \\
\text { uygulanmaktadır. }\end{array}$ \\
\hline $\begin{array}{c}\text { Koçak ve } \\
\text { Karkın (2010) }\end{array}$ & $\begin{array}{l}\text { BKA'ların etkinliğini çoklu } \\
\text { paydaş kuramı ile analiz } \\
\text { etmektir. }\end{array}$ & $\begin{array}{l}\text { Doküman } \\
\text { Analizi }\end{array}$ & $\begin{array}{l}\text { BKA'lar, merkezin siyasal, } \\
\text { yerelin de sosyal baskısına } \\
\text { uğrayabilir. }\end{array}$ \\
\hline $\begin{array}{l}\text { Helvacioğlu } \\
\text { ve Tektaş } \\
\text { (2010) }\end{array}$ & $\begin{array}{l}\text { Yönetişimin kalkınmaya } \\
\text { etkisini, BKA'lar örneğinde } \\
\text { incelemektir. }\end{array}$ & $\begin{array}{l}\text { Doküman } \\
\text { Analizi }\end{array}$ & $\begin{array}{l}\text { Etkin fon kullanımı ve } \\
\text { BKA'lar arasında doğrudan } \\
\text { bir ilişki vardır. }\end{array}$ \\
\hline Özışık (2012) & $\begin{array}{l}\text { Kentsel } \quad \text { yönetişim } \\
\text { kavramını, } \\
\text { getirdiği model } \\
\text { örneğların İzmin } \\
\text { örne incelemektir. }\end{array}$ & $\begin{array}{l}\text { Doküman } \\
\text { Analizi }\end{array}$ & $\begin{array}{l}\text { BKA'ların kurulmasıyla } \\
\text { devletçi anlayıştan liberal } \\
\text { anlayışa geçiş, kamu, özel ve } \\
\text { sivil aktörlerin işbirliğinde } \\
\text { gerçekleşmektedir. }\end{array}$ \\
\hline $\begin{array}{c}\text { Güney ve Sat } \\
\text { (2016) }\end{array}$ & $\begin{array}{l}\text { BKA'ların planlama } \\
\text { faaliyetlerini yönetişim } \\
\text { temelinde incelemektir. }\end{array}$ & $\begin{array}{c}\text { Anket, } \\
\text { Mülakat }\end{array}$ & $\begin{array}{lr}\begin{array}{l}\text { Yönetişim, bölge } \\
\text { hazırlamanın }\end{array} & \text { planını } \\
\text { uygulama ve } & \text { izleme } \\
\text { sürecinde } \\
\text { uygulanmalıdır. }\end{array}$ \\
\hline Arslan (2016) & $\begin{array}{l}\text { BKA'ların bir yönetişim } \\
\text { örneği olup olmadığını } \\
\text { sorgulamaktır. }\end{array}$ & $\begin{array}{l}\text { Doküman } \\
\text { Analizi }\end{array}$ & $\begin{array}{l}\text { BKA'lar, yönetişim ilkelerini } \\
\text { uygulayabilecek düzeyde } \\
\text { değildir. }\end{array}$ \\
\hline $\begin{array}{l}\text { Ertugal } \\
(2017)\end{array}$ & 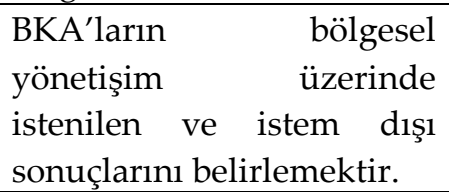 & $\begin{array}{l}\text { Doküman } \\
\text { Analizi, } \\
\text { Anket }\end{array}$ & 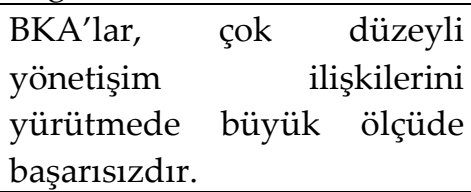 \\
\hline
\end{tabular}

*Çalışmalar, BKA'larda yönetişim yaklaşımı ile doğrudan ilgili olanlar arasından seçilmiştir.

**Kimi çalışmalarda, yöntem belirtilmemiştir. Bu, yazar tarafından belirlenmiştir.

Kaynak: Yazar tarafından geliştirilmiştir.

Tablo 3'e göre Türkiye'de BKA'lar, yönetişim yaklaşımı ile çeşitli yönlerden incelenmiştir. BKA'ları Karakılçık ve Sarıgül (2010) ile Özışık (2012), kapitalizm ve sermayenin hegemonya stratejisi; Güney ve Sat (2016), planlama faaliyetleri; Lagendijk et. al. (2009), Koçak ve Karkın (2010) ile Ertugal (2017), çok düzeyli yönetişim; Helvacioğlu ve Tektaş (2010), etkinlik; Arslan (2016), yönetişim ilkeleri ile incelemişler.

\section{IZMIR KALKINMA AJANSI}

Türkiye'de BKA'lar, AB'nin etkisi ile kurulmuştur. Helsinki Zirvesi'nde (1999) Türkiye'ye $A B^{\prime} y e$ “aday ülke” statüsü verilmiştir. $A B^{\prime}$ ye uyum sürecinde bölgesel 
politika alanında yapılan yasal ve kurumsal düzenlemeler ile 5449 sayılı BKA Kanunu (2006) çıkarılmış; 26 tane BKA (2006-2009) ve Kalkınma Bakanlığ ${ }^{7}$ (2011) kurulmuştur.

BKA'ların amacı, aktörler arasında işbirliğini geliştirmek, yerel potansiyeli harekete geçirmek, bölgesel gelişmeyi sağlamak, bölge içi ve bölgeler arası gelişmişlik farkını azaltmaktır (md. 18). Kalkınma Kurulu (KK), Yönetim Kurulu, Genel Sekreterlik ve Yatırım Destek Ofisi şeklinde örgütlenmiştir (md. 7). KK, yerel aktörlerden seçilen en fazla yüz üyeden oluşmuştur (md. 8). Yönetim Kurulu, ajansın karar organıdır. Kurulun başkanı validir (md. 10). Genel Sekreterlik, ajansın icra organıdır (md. 12). Yatırım Destek Ofisi ise, yerel aktörlere hizmet vermektedir (md. 15).

Türkiye'de ilk olarak 2006 yılında kurulan iki pilot BKA'dan biri', IZZKA'dır. İZKA, Türkiye'nin ilk kalkınma ajansı olan Ege Bölgesi Kalkınma Ajansı (EBKA, 1993) deneyiminin de etkisiyle İzmir'de kurulmuştur. İzmir, yaklaşık 4 milyon nüfusa sahip olup; Ege Bölgesi'nin en büyük ve en gelişmiş kentidir. Türkiye'de sosyo-ekonomik gelişmişlik bakımından 3. sıradadır (İZKA, 2010: 20-23).

İZKA'nın temel amaçları şunlardır (İZKA, 2011a: 19; İZKA, 2012c: 18):

- Yerel aktörler arasında işbirliğini geliştirmek,

- Bölgenin rekabet gücünü artırmak,

- Bölgenin sürdürülebilir kalkınmasını sağlamaktır.

İzmir'in kalkınması için planlama ve yenilikçilik faaliyetlerini ${ }^{10}$ yürütmüştür (Çelik, 2015: 119). Yerel aktörlerle hazırlanan orta ve uzun vadeli planlarda ${ }^{11}$, İzmir'in kalkınma eksenleri, hedefleri ve öncelikleri belirlenmiştir (İZKA, 2012: 30). İZKA'nın yerel katılıma dayalı planlama anlayışı, Türkiye için yeni bir olgudur ve İzmir'de yönetişim yaklaşımını geliştirmiştir (Özışık, 2015: 337-338).

IZZKA, yenilikçilik faaliyetleri ile yerel aktörlerle Kümelenme Stratejisi (2009) ve Yenilik Stratejisi (2012) geliştirmiştir. Türkiye'de BKA'lar arasında ilk olan bu stratejilerin temel amacı, İzmir'in yenilikler temelinde kalkınmasını sağlamaktır.

Türkçe literatürde en çok analiz edilen ajanslardan biri, İZKA'dır. İZKA'ya ilişkin başlıca çalışmalar, konularına göre planlama ve kümelenme faaliyetleri ile etki analizi ve kalkınma kurulu şeklinde tasnif edilerek, Tablo 4 'de sunulmuştur.

\footnotetext{
7 BKA'ları koordinasyon görevini üstlenen Devlet Planlama Teşkilatı'nın (DPT) yerine 2011 yılında Kalkınma Bakanlığı kurulmuştur.

${ }^{8}$ BKA'ların amacı, yönetimi ve faaliyetlerine ilişkin bilgiler, 5449 sayılı BKA Kanunu'ndan yararlanılarak düzenlenmiştir. Yapılan alıntılar, madde (md.) numarası ile belirtilmiştir.

${ }^{9}$ İkinci pilot BKA ise, Adana ve Mersin'de kurulan Çukurova Kalkınma Ajansı'dır (ÇKA).

10 Yenilikçilik faaliyetleri kısaca, bölgenin yenilik yapma kapasitesini geliştirmeye yönelik kümelenme, yenilik ve ağ faaliyetleri şeklinde tanımlanabilir (Çelik, 2015: 4).

${ }^{11}$ Bunlar, 2009-2013 Bölge Planı, 2010-2013 Bölge Planı ve 2014-2023 Bölge Planı.
} 
Tablo 4. İZKA'ya İlişkin Literatür Özeti

\begin{tabular}{|c|c|c|c|}
\hline Konu & Yazarı & Amac1 & Sonucu \\
\hline \multirow{4}{*}{ 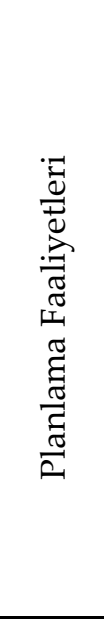 } & $\begin{array}{l}\text { Aydoğdu } \\
\text { (2010) }\end{array}$ & $\begin{array}{l}\text { 2009-2013 Bölgesel Gelişme } \\
\text { Planı'nı incelemektir. }\end{array}$ & $\begin{array}{l}\text { Planlama faaliyetlerinin } \\
\text { etkinliği, yerel aktörlerin katılımı } \\
\text { ile artacaktır. }\end{array}$ \\
\hline & $\begin{array}{l}\text { Akpinar } \\
(2010)\end{array}$ & $\begin{array}{l}\text { 2010-2013 Bölge Planı'nı } \\
\text { incelemektir. }\end{array}$ & $\begin{array}{l}\text { Plan, yönetişim modeline göre } \\
\text { yerel aktörlerle } \\
\text { hazırlanmıştır. }\end{array}$ \\
\hline & $\begin{array}{l}\text { Burak } \\
(2011)\end{array}$ & $\begin{array}{l}\text { Planlama faaliyetlerini, 2010- } \\
2013 \text { Bölge Planı ile } \\
\text { incelemektir. }\end{array}$ & $\begin{array}{l}\text { BKA'lar, planlama sürecinde } \\
\text { yalnızca "veri toplayan bir } \\
\text { aktör"dür. }\end{array}$ \\
\hline & $\begin{array}{l}\text { Eldeniz } \\
(2011)\end{array}$ & $\begin{array}{lr}\text { İZKA'nın } & \text { kurumsal } \\
\text { performansını, } & \text { 2010-2013 } \\
\text { Bölge Planı'na göre } \\
\text { belirlemektir. }\end{array}$ & $\begin{array}{l}\text { İZKA, planin koordinatörü, } \\
\text { destekleyicisi ve katalizörüdür. }\end{array}$ \\
\hline \multirow{3}{*}{ 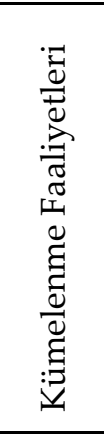 } & $\begin{array}{l}\text { Özdemir ve } \\
\text { İneler } \\
(2009) \\
\end{array}$ & $\begin{array}{l}\text { İZKA'nın kümelenme } \\
\text { faaliyetlerini incelemektir. }\end{array}$ & $\begin{array}{l}\text { İZKA'nın kümelenme } \\
\text { faaliyetleri, BKA'lar tarafından } \\
\text { örnek alınabilir. }\end{array}$ \\
\hline & $\begin{array}{l}\text { Haşar ve } \\
\text { İneler } \\
(2011) \\
\end{array}$ & $\begin{array}{l}\text { İZKA'nın kümelenme } \\
\text { faaliyetlerini incelemektir. }\end{array}$ & $\begin{array}{l}\text { İZKA'nın kümelenme } \\
\text { faaliyetleri, BKA'lar tarafından } \\
\text { örnek alınabilir. }\end{array}$ \\
\hline & $\begin{array}{l}\text { Günaydın } \\
\text { (2013a) }\end{array}$ & $\begin{array}{l}\text { İZKA'nın kümelenme } \\
\text { faaliyetlerini incelemektir. }\end{array}$ & $\begin{array}{l}\text { İZKA'nın kümelenme } \\
\text { faaliyetleri, BKA'lar tarafından } \\
\text { örnek alınabilir. }\end{array}$ \\
\hline \multirow{4}{*}{ 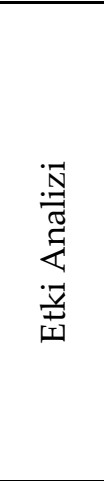 } & $\begin{array}{l}\text { İKA } \\
(2011)\end{array}$ & $\begin{array}{l}\text { Mali Destek Programları'nın } \\
(\mathrm{MDP}) \quad \text { etkinliğini analiz } \\
\text { etmektir. }\end{array}$ & $\begin{array}{l}\text { MDP'ler, işletmelerde ciro ve } \\
\text { istihdam artışına yol açmıştır. }\end{array}$ \\
\hline & İçen (2012) & $\begin{array}{l}\text { İZKA'nın yerel kalkınmaya } \\
\text { katkısını tespit etmektir. }\end{array}$ & $\begin{array}{lr}\text { İZKA, MDP aracılığıyla kırsal } \\
\text { kalkınmaya } \\
\text { bulunmuştur. }\end{array}$ \\
\hline & $\begin{array}{l}\text { Ersayın } \\
(2012)\end{array}$ & $\begin{array}{l}\text { MDP'lerin yerel kalkınmaya } \\
\text { katkısını ortaya koymaktır. }\end{array}$ & $\begin{array}{l}\text { MDP'lerin \% 50'sinin, yerel } \\
\text { kalkınmaya etkisi yoktur. }\end{array}$ \\
\hline & $\begin{array}{l}\text { Günaydın } \\
(2013 b)\end{array}$ & $\begin{array}{l}\text { MDP'lerin yerel kalkınmaya } \\
\text { etkisini belirlemektir. }\end{array}$ & $\begin{array}{l}\text { MDP'ler, İzmir'de eğitim ve } \\
\text { istihdam düzeyini artırmıştır. }\end{array}$ \\
\hline \multirow{3}{*}{ 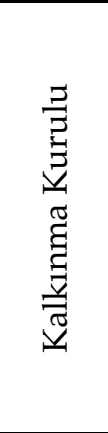 } & Çelik (2016) & $\begin{array}{lr}\begin{array}{l}\text { Kalkınma } \\
\text { gündem }\end{array} & \begin{array}{r}\text { Kurulu'nun } \\
\text { belirleme }\end{array} \\
\text { faaliyetlerini incelemektir. }\end{array}$ & $\begin{array}{l}\text { KK, İzmir'in kalkınmasına } \\
\text { yönelik gündemler belirlemiştir. }\end{array}$ \\
\hline & $\begin{array}{l}\text { Çelik } \\
(2017 b)\end{array}$ & $\begin{array}{lr}\begin{array}{l}\text { Kalkınma } \\
\text { etkinliğini }\end{array} & \begin{array}{r}\text { Kurulu'nun } \\
\text { girişimlerini belirlemektir. }\end{array} \\
\end{array}$ & $\begin{array}{lrr}\text { KK, kendini, İZKA'yı ve } & \text { BKA } \\
\text { Kanunu'nu sorgulamış } & \text { ve } \\
\text { öneriler geliştirmiştir. } & \\
\end{array}$ \\
\hline & $\begin{array}{l}\text { Akpinar } \\
(2017)\end{array}$ & $\begin{array}{lr}\text { Kalkınma } & \text { Kurulu'nun } \\
\text { sorunlarını ve } & \text { etkinliğini } \\
\text { ortaya koymaktır. }\end{array}$ & $\begin{array}{l}\text { Kalkınma Kurulu'nun daha } \\
\text { etkin olması gerektiği sonucuna } \\
\text { ulaşmıştır. }\end{array}$ \\
\hline
\end{tabular}

Kaynak: Yazar tarafından geliştirilmiştir.

Tablo 4'e göre Aydoğdu (2010), Akpınar (2010), Burak (2011) ve Eldeniz (2011), İZKA'nın planlama faaliyetlerini; Özdemir ve İneler (2009), Haşar ve İneler (2011) ile 
Günaydın (2013a) ise, kümelenme faaliyetlerini incelemişler. İZKA (2011), İçen (2012), Ersayın (2012) ve Günaydın (2013b), IZZKA'nın desteklediği projelerle İzmir'in kalkınmasına katkısını belirlemişler. Çelik (2016), İZA Kalkınma Kurulu'nun gündem belirleme; Çelik (2017b) ve Akpınar (2017) ise, etkinliğini artırma girişimlerini ortaya koymuşlar. Bu araştırmada ise İZKA KK, yönetişim yaklaşımı ile incelenmiştir.

\section{ARAŞTIRMANIN AMACI, YÖNTEMİ, SINIRLARI VE SINIRLILIĞI}

BKA'lar, yönetişime dayalı bir örgüt olarak kabul edilir. Başlıca görevlerinden biri, yerel aktörleri ortak bir amaç için bir platformda buluşturmak ve yarattığ1 sinerji ile bölgesel kalkınmayı hızlandırmaktır. Bu bakımdan yerel aktörlerden oluşan KK, bölgede katılım, müzakere ve uzlaşma kültürünü geliştirerek yönetişimi sağlayan önemli yapılardan biridir (Akpınar, 2017: 303).

BKA'larda yönetişim öncelikle KK'da uygulanır. Ancak Türkiye'de BKA'ların, hedeflendiği gibi yönetişimci bir yapıda olmadığ1; KK'da yerel aktörlerin yer almasının ajansları katılımcı bir örgüte dönüştürmediği belirtilmiştir. Bu eleştiriler, şu hususlara dayanmıştır (Özer, 2009: 175-177, 309; Karasu, 2015: 282; Arslan, 2016: 35-36):

- BKA'ların katılımcı bir örgüt olmadığı, yapılan araştırmalarda ortaya konmuştur. Mesela DDK Raporu'nda (2014: 779), KK toplantılarına katılımın düşük düzeyde kaldığı ve giderek daha da düştüğü, hatta yılda en az iki kere toplanması gereken KK'nın buna da uymadığı belirtilmiştir.

- Merkezi yönetimin temsilcisi valinin Yönetim Kurulu başkanı olması, literatürde BKA'ların merkeziyetçi bir yapıda olduğuna yönelik eleştirileri güçlendirmiştir.

- KK'da temsil edilecek kurumların, valinin görüşü ile merkezi yönetim (Kalkınma Bakanlığı) tarafından belirlenmesi, ajansın yönetişim yapısını zayıflatmıştır. Bu durumda BKA'larda yönetişimden (heterarşik yapı) ziyade yönetimin (hiyerarşik yapı) egemen olacağ ${ }_{1}$ vurgulanmıştır.

- 2008/14306 sayılı Bakanlar Kurulu Kararı'nda, KK'da yer alacak aktörlerin, ildeki etki ve ekinlikleri gibi ölçülere göre nasıl tespit edileceğinin belirtilmemesi, yönetişimden ziyade yönetim görüntüsü vermiştir.

- KK, ajansın karar organı değildir; danışma meclisi konumundadır. Dolayısıyla kurulda alınan kararların bağlayıcılığı yoktur; yalnızca tavsiye niteliğindedir. Bu durum üyelerde, KK'nın etkisiz ve yetkisiz bir yapı olduğuna dair kanaat oluşturmuştur.

Yönetişim yaklaşımı, AB'ye göre 5 ilkeye dayanmaktadır. Bunlar, açıklık, katılımcılık, hesap verebilirlik, etkinlik ve uyum'dur (CEC, 2001: 10). Karar alma, uygulama ve denetleme gibi boyutları içeren katılımcılık ${ }^{12}$, kamu gücünün kötüye

\footnotetext{
12 Yönetişimde merkezi bir öneme sahip olan katılımcılık, kamunun karar verme yetkisinin, özel ve sivil kesimlerle paylaşılmasıdır. Ancak katılımcılık, kamunun karar mekanizmalarında sermayenin etkinliğini artırma ve toplumun diğer kesimlerini dışlama riskine sahiptir. Yönetişim, çok aktörlü ve katılımcı bir yönetim olarak tanımlansa da sermaye kesiminin çıkarlarını öne çıkaran bir modeldir. Bu modele dayalı kalkınma anlayışı, toplumda yoksulluk ve eşitsizlik yaratır (Özkan et al., 2012: 95).
} 
kullanılmasını önlemek, kamusal düzenlemelere uyumu artırmak, paydaşlar arasında uzlaşma sağlamak gibi yönlerden önemlidir (Güney ve Sat, 2016: 103-104).

$\mathrm{Bu}$ araştırmanın amacı, İZKA örneğinde KK'nın oluşum ve işleyiş sürecinin, çalışma kapsamında geliştirilen ve Tablo 5'de sunulan kriterlere göre yönetişim yaklaşımının katılımcılık ilkesi temelinde analiz etmektir.

Tablo 5. Kalkınma Kurulu'nu Yönetişim Yaklaşımı İle Değerlendirme Kriterleri

\begin{tabular}{|c|c|c|}
\hline Kriter & Süreç & Boyutu* \\
\hline $\begin{array}{l}\text { - Üyelerin toplumsal kesimlere (kamu-özel-sivil) göre } \\
\text { dağıllımı }\end{array}$ & \multirow{2}{*}{$\begin{array}{c}\text { Kurulun } \\
\text { oluşum } \\
\text { süreci }\end{array}$} & \multirow{2}{*}{$\begin{array}{c}\text { Yönetişimin } \\
\text { pasif } \\
\text { boyutu }\end{array}$} \\
\hline $\begin{array}{l}\checkmark \text { Özel ve sivil kesim üyelerinin kendi içindeki } \\
\text { dağılımı }\end{array}$ & & \\
\hline - Üyelerin kurul toplantılarına katılımı/devam durumu. & \multirow{2}{*}{$\begin{array}{l}\text { Kurulun } \\
\text { işleyiş } \\
\text { süreci }\end{array}$} & \multirow{2}{*}{$\begin{array}{c}\text { Yönetişimin } \\
\text { aktif } \\
\text { boyutu }\end{array}$} \\
\hline $\begin{array}{l}\text { - Kurulda oluşturulan çalışma grubu ve çalışma komitesi } \\
\text { sayısı }\end{array}$ & & \\
\hline
\end{tabular}

*Yönetişimin aktif ve pasif boyutu şeklindeki ayırımı, yazar tarafından yapılmıştır.

Kaynak: Şimşek $(2013: 33,36)$ ve Çelik'den $(2016,2017 b)$ yararlanılarak yazar tarafından geliştirilmiştir.

Tablo 5'e göre KK, üyelerin toplumsal kesimler itibariyle dağılımına ve toplantılara katılım durumuna, oluşturulan çalışma grubu ve çalışma komitesine göre yönetişim temelinde incelenebilir. Bunlardan birinci kriter, yönetişim yaklaşımının pasif boyutu; diğerleri ise aktif boyutu olarak nitelendirilebilir.

Çalışma, 2008-2014 döneminde oluşturulan İZKA KK'nın yönetişim yaklaşımı temelinde analizi ile sınırlandırılmıştır. İZKA'nın seçilmesinin nedenleri, İzmir'in BKA ve yönetişime dair başlica şu deneyimleridir (Temizocak, 2006: 389-395; Lagendijk et al., 2009: 387; Özışık,2012: 138-140; Kayasü and Eldeniz, 2013: 67; Özışık, 2015: 335-338):

- Ege bölgesinin (İzmir ve çevresi) kalkınması için 1992 yılında kurulan Ege Ekonomiyi Geliştirme Vakfı'nın (EGEV ${ }^{13}$ ) tüm bölgeyi kapsayacak şekilde "aşağıdan yukarıya" doğru geliştirdiği yerel kalkınma girişimleri, İzmir'de güçlü bir yönetişim yapısının olduğunu göstermiştir.

- İzmir'in BKA konusundaki ilk deneyimi, Ege Bölgesi Kalkınma Ajansı'dır (EBKA). İzmir Ticaret Odası'nın (İZTO) ve AB'nin işbirliğinde 1993 yılında kurulan EBKA, Türkiye'nin ilk bölgesel kalkınma ajansıdır. Misyonu, ortak akıl ve katılımcılık ile bölgeye özgü bir kalkınma modeli geliştirmektir. 1995 yılında EGEV'in bünyesinde anonim şirkete dönüştürülmüştür.

- İzmir'de yerel aktörlerden oluşan Başkanlar Kurulu ${ }^{14}, 1990^{\prime}$ lardan beri her ay toplantı yapmaktadır.

13 EGEV, İzmir Valiliği'nin öncülüğünde kamu, özel ve sivil kesimlerin katılımıyla bölgeyi dış yatırımcılara tanıtmak amacıyla 1992 yılında kurulmuştur. 1998 yılında İzmir'in yanısıra 9 kentin yerel aktörlerinin de katılımıyla tüm Ege bölgesini kapsamıştır.

${ }^{14}$ Kurulun bazı üyeleri şunlardır: İZTO Başkanı, EBSO Başkanı, İzmir Borsası Başkanı, İzmir İhracatçılar Birliği Başkanı, İzmir Ziraat Odası Başkanı, EGEV Başkanı, Batı Anadolu Sanayici ve İşadamları Derneği. 
- 2004 yılında kurulan ve önde gelen 21 tane gönüllü kanaat önderinin yer aldığ 1 İzmir İçin Yeni Sinerjiler Enstitüsü (“İzmir Enstitüsü”), tüzel kişiliği olmayan bir fikir platformudur. İzmir'in yanısıra Türkiye'nin sosyo-ekonomik sorunlarına yönelik projeler geliştirmekte ve bunları ilgili kurumlarla paylaşmaktadır. Yaz ayları hariç her ay toplanmaktadır.

- İzmir Büyükşehir Belediyesi'nin (İBB) öncülügüünde 2009 yılında kurulan İzmir Ekonomik Kalkınma ve Koordinasyon Kurulu (İEKKK ${ }^{15}$ ), kentin ekonomisinde belirleyici role sahip 81 kurumun temsilcisinden oluşmuştur.

- İzmir, Türkiye'de BKA'ların kuruluş sürecinde önemli bir rol oynamıştır. 1990'l1 yıllardan itibaren İTO ve EGEV, merkezi yönetime BKA'ların kurulmasını önermiştir. Bu konuda İZKA KK üyesi U. Yüce, kurulun 07.09.2011 tarihinde yapılan toplantıda 5449 sayılı BKA Kanunu'nun temelinin EGEV'in bir çalışmasına dayandığını ifade etmiştir.

- Türkiye'deki iki pilot BKA'dan biri olan İZKA'nın kurulması, İzmir'in, “ortak aktör" kavramının temelini oluşturan sosyal sermayeye ${ }^{16}$ sahip bir kent olduğunu göstermiştir. İKA, yönetişime dayalı örgütsel yapısı ve yerel kalkınma faaliyetleri ${ }^{17}$ ile İzmir'deki yönetişim yapılarının kurumsallaşmasına katkıda bulunmuştur.

- Kısaca İzmir, EGEV, EBKA, Başkanlar Kurulu, İzmir Enstitüsü, İEKKK ve İZKA gibi Türkiye'de model olabilecek yönetişim yapılarına sahiptir.

Çalışma, nitel araştırma yöntemlerinden doküman analizi tekniği ile yapılmıştır. Konuya ilişkin yazılı materyallerin incelenmesi olan doküman analizi, beş aşamada yapılabilir. Bunlar, dokümanlara ulaşma, orjinalliğini kontrol etme, dokümanları anlama, verileri analiz etme ve kullanma (Yıldırım ve Şimşek, 2013: 217218, 223).

Çalışmanın başlıca sınırlılığı, KK'nın oluşum ve işleyiş sürecine ilişkin verilerin kısıtlı olmasıdır. Bu sinırlılık, İZKA KK'nın 2008-2014 döneminde yaptı̆̆ 20 toplantının karar tutanakları (485 s.), karar özetleri (114 s.) ve sonuç bildirgelerinden (29 s.) "veri"ler derlenerek aşılmaya çalışılmıştır. Analizde İZK'nın ve Devlet Denetleme Kurumu'nun (DDK) raporlarından da yararlanılmıştır.

\section{BULGULAR ${ }^{18}$}

Bu bölümde, İZKA KK'nın oluşum ve işleyiş sürecinde uygulanan yönetişim yaklaşımı, Tablo 5'deki kriterlere göre ortaya konmuştur.

\footnotetext{
${ }^{15}$ EKKK'nın bazı üyeleri şunlardır: MÜSİAD İzmir Başkanı, DEÜ Rektör Yardımcısı, İZSİAD Başkanı, İBB Başkanı, İZKA Genel Sekreteri, TMMOB İzmir Başkanı, Deniz Ticaret Odası Başkanı, IZTO Başkanı.

${ }^{16}$ Sosyal sermaye kısaca, güven ve işbirliğine dayalı ilişkileri, bilinçli vatandaşları ve sivil toplumu ifade etmektedir.

${ }^{17}$ Bu konuda İZKA'nın yönetişim temelinde geliştirdiği Kümelenme Stratejisi (2008) kapsamında kurduğu Kümelenme Komitesi ile Yenilik Stratejisi (2012) çerçevesinde oluşturduğu Yenilik Komitesi ile Yenilik Teknik Komitesi, örnek olarak verilebilir.

${ }^{18}$ Bulgular, literatürde BKA'lara yöneltilen eleştiriler temelinde yorumlanmaya çalışılmıştır.
} 


\subsection{Kalkınma Kurulu Üyelerinin Toplumsal Kesimlere Göre Dağılımı}

İZKA KK, 5449 sayılı kanuna göre 2006-2017 döneminde yerel aktörlerden ve merkezi yönetimin taşra temsilcilerinden seçilen 100 üyeden oluşmuştur. Bu üyelerden 3 tanesi, yönetim kuruluna seçilmiştir. İZKA KK Başkanı N. Kalkan, kurulun yönetişim yapısını 05.05.2011 tarihinde yapılan toplantıda şöyle ifade etmiştir: “ ... şu kurulun listesini alın. Bir bakın bakalım. Belediye başkanları var mı, valiler var mı, kaymakamlar var ml, rektörler var mi, profesörler var ml, sivil toplum örgütlerinin, sanat dünyasının, sendikaların temsilcileri var ml, var. Peki böyle bir kurul Türkiye'de nerde var? İlk defa İzmir'de kuruldu. ..."

Kurulun yönetişim yapısı, kamu-özel-sivil kesim temsilcilerinin sayısına göre belirlenebilir. Buna ilişkin “veri”ler, 2013-2017 Dönemi Kalkınma Kurulu Üyeleri çizelgesinden hesaplanarak Tablo 6' da sunulmuştur.

Tablo 6. Kalkınma Kurulu Üyelerinin Toplumsal Kesimlere Göre Dağılımı (2006-2017)

\begin{tabular}{|l|l|l|c|}
\hline Kesim & 2006-2007* & 2008-2012 & 2013-2017** \\
\hline$\bullet$ Kamu Kesimi & & & 30 \\
\hline$\bullet$ Özel Kesim & & & 42 \\
\hline$\checkmark$ Sermaye Sinıf1 & & & 41 \\
\hline$\checkmark$ Emek Sinıf & & & 1 \\
\hline$\bullet \quad$ Sivil Kesim & & & 25 \\
\hline Toplam & & & 97 \\
\hline
\end{tabular}

*Bu dönemlerde, üyelerin kesimlere göre dağılımına ilişkin çizelge yayınlanmamıştır. 2006/10550 sayılı ve 2008/14306 sayılı Bakanlar Kurulu kararları ile oluşturulan İKA KK'nın kamu (\% 30) ve özel-sivil (\% 70) kesim üyelerinden oluştuğu belirtilmiştir (Eldeniz, 2011: 111; Özer, 2009: 177-178).

**Üyelerin “kamu-özel-sivil kesim” itibariyle tasnifi, yazar tarafından yapılmıştır.

Kaynak: Çizelgeden yararlanılarak yazar tarafından geliştirilmiştir.

Tablo 6'ya göre 2013-2017 döneminde KK üyelerinin kamu, özel ve sivil kesim itibariyle dağılımı sırasıyla şöyledir: 30, 42 ve 25. Kamu kesimi üyeleri, merkezi yönetimin taşra temsilcileridir. Özel ve sivil kesim üyeleri ise, yerel aktörlerden oluşmuştur. Buna göre İZKA'nın kurulda, merkezi ve yerel aktörlerin katılımını sağladığı; dolayısıyla kurulun oluşum sürecinde, yönetişim yaklaşımını (pasif boyutu) uyguladığı söylenebilir. Ancak bu durumun da ajansı, "merkezin siyasal, yerelin de sosyal baskısı"na maruz bırakabileceği (Koçak ve Karkın, 2010) belirtilebilir.

Kurulda özel kesim üyelerinin kendi içindeki dağılımı da bir alt kriter olabilir. 2013-2017 döneminde özel kesim içinde sermaye sınıf $1^{19}$ önemli bir paya (41/42: \% 97) sahip iken; emek sınıfının temsilcisi, yalnızca bir tanedir (Hak-İş Konfederasyonu). Buna göre kurulda, yönetişim modelinin tam olarak uygulanmadı̆̆ı; kurulun, "sermaye yoğun" (\% 41) bir yapıya sahip olduğu ve "sermayenin egemenliği" altında faaliyet gösterdiği (Müftüoğlu, 2012; Özkan et al., 2012); bunun, “sermaye kesiminin

${ }^{19}$ KOBÍlerin (11 tane), Organize Sanayi Bölgeleri'nin (4 tane), Serbest Bölgelerin (2 tane), ticaret odalarının (8 tane), deniz ticaret odasının (1 tane), sanayi odasının (1 tane) ve "sanayici ve iş adamları dernekleri" nin (14 tane), sermaye kesimini temsil ettiği varsayılmıştır. 
daha da güçlenmesi”ni sağlayabileceği (Özkan et al., 2012); sonuçta İZKA'nın, "bölge refahını adil bir şekilde dağıtamayacağı" (Çalt, 2005) söylenebilir ${ }^{20}$.

Yönetişime dair ikinci alt kriter, kurulda sivil kesim temsilcilerinin kendi içindeki dağılımı olabilir. Toplumun önemli bir kısmını oluşturan dezavantajlı kesimlerin (kadınlar ve engelliler), 2013-2017 döneminde KK'da düşük düzeyde temsil edildiği gözlenmiştir. KK'da 19 dernek ${ }^{21}$, 2 vakıf, 3 birlik ve 1 de konfederasyon arasında sivil kesimi temsil eden 7 tane kurum $^{22}$ olduğu; dolayısıyla kurulda, sivil kesimin kendi içindeki dağılımı bakımından da yönetişimin kısmen uygulandığı ifade edilebilir.

\subsection{Kalkınma Kurulu Üyelerinin Kurul Toplantılarına Katılım Durumu}

KK'nın işleyiş sürecinde uygulanan yönetişim (aktif boyutu), üyelerin toplantılara ${ }^{23}$ katılım durumuna göre de tespit edilebilir. Tutanaklarda, üyelerin toplantılara katılımı konusunda bir "devamsızlık sorunu" ${ }^{24}$ olduğu belirtilmiştir. Bu sorun, KK üyeleri tarafından da dile getirilmiştir.

KK Başkanı N. Kalkan, 12.07.2010 tarihinde yapılan toplantıda katılım konusunda şunları söylemiştir: "Tam 22 tane arkadaşım bugün benden mazeret izni aldı. Bu kurulun çalışmasıyla ilgili inanın devam durumundan bazı rahatsıllıklar var. Bu kurula seçilmek için ... bin bir zorlukla ... seçiliyorlar. Sonra da bir iki sebeple gelmiyorlar. Gelmeyince kurulun istediği çalışmayı ortaya koyması mümkün olmuyor.".

U. Yüce, 02.02.2011 tarihindeki toplantıda bu konuda “... 59 imza var iki kişi daha geldi, 61 kişiyiz. 39 kişi yok. 22'si mazeretli, diğerleri mazeretli bile değil. Zaten üç ayda, altı ayda çalışan bir kurulun bu kadar önceden belli olmuş ve bu kadar önemli gündem maddesi olan toplantısına bile gelmiyorsak bunun da nedenlerinin irdelenmesi icap eder diye düşünüyorum." demiştir.

B. Akgerman, 05.05.2011 tarihinde yapılan toplantıda devamsızlık sorununu “... toplantıda çok fazla mazeretli üye olduğunu duydum. ... bu güzide kurula girmek için çok ciddi ... çalışmalar yürütüldü. ... Fakat bu zaman içerisindeki heyecanın yok oluşunu ... gözlemliyordum, duyuyordum." şeklinde belirtmiştir.

İZKA Genel Sekreteri E. Can, 08.12.2011 tarihindeki toplantıda, “Bugün ne kadar katılım var diye baktık. Altmış kişi katılım sağlamış yüz kişiden. Tabii bu şunu gösteriyor. Biz kurul çok iyi çalışsın, çok etkin çalışsın diye burada bir taraftan çalışmalar yapılırken ... katılım da bu şekilde oluyor..." sözleriyle devamsızlık sorununu vurgulamıştır.

\footnotetext{
20 Yönetişim, bu yönlerden “yoksulluk, sosyal adalet ve eşitlik gibi kavramlara kör bir yönetişimci kalkınma modeli" ve "yeni bir hegemonya stratejisi" olarak değerlendirilmiştir (Özkan et al., 2012: 90).

${ }^{21}$ Derneklerin büyük bir kısmı (14 tane), sanayici ve iş adamları dernekleridir.

${ }^{22} \mathrm{Bu}$ kurumlar şunlardır: İzmir Kültür ve Sanat Vakfı, Yeni Oluşum Derneği, Çiğliye Gönülverenler Kültür ve Dayanışma Derneği, İzmir Sivil Toplum Örgütleri Platformu, Kordelyalılar Derneği, Ege Turizm Derneği, İzmir Kültürlerarası Diyalog Merkezi.

${ }^{23}$ İKA KK, ilk toplantısını 04.08.2006 tarihinde yapmıştır.

${ }^{24}$ BKA'larda KK üyelerinin devamsızlık sorunu, Devlet Denetleme Kurulu (DDK, 2014: 779) tarafından da “..., kurul toplantılarına katılımın çok düşük düzeyde kaldığı, ..., düşük katılım düzeyinin yıllar itibariyle aşağı yönlü eğilimini devam ettirdiği..." şeklinde belirtilmiştir.
} 
KK Başkanı K. Çolakoğlu ise, devamsızlık sorununu 26.12.2013 tarihinde yapılan toplantıda "Öncelikle hemen sizlerden özür dileyeyim, yirmi dakika geç başladık. Ama yirmi dakikada çoğunluğumuzu ancak să̆ladık. İstiyoruz, Kalkınma Kurulumuz daha enerjik, daha dinamik, daha fazla çoğunlukla toplansin...".; 10.04 .2014 tarihindeki toplantıda ise "... bugün 62 kişi var. 97'e 62. Bu 62 kişinin 11'i vekaleten katılıyor. 17 kişi de mazeret bildiriyor. ... daha önceki aylarda da konuştuğumuz gibi katılımda sıkıntılarımız var." şeklinde ifade etmiştir.

Tutanaklarda daha ziyade toplantılara mazeretli olarak katılmayan üyelerin sayısı belirtilmiştir. Toplantılara mazeretli ve mazeretsiz katılmayan üyelerin tespiti, 12.07.2010 tarihindeki toplantıdan itibaren yapılmıştır. Ancak toplam devamsız üye sayısı, tutanaklarda yine belirtilmemiştir. Bu nedenle 2008-2014 döneminde yapılan toplantılara katılan üye sayısı, "mazeretsiz devamsız" ve "mazeretli devamsız" üye sayısına göre tespit edilerek Tablo 7' de ve Grafik 1'de sunulmuştur.

Tablo 7. Kalkınma Kurulu Toplantılarına Katılan ve Katılmayan Üye Sayısı (2008-2014)

\begin{tabular}{|c|c|c|c|c|}
\hline Sira No & $\begin{array}{l}\text { Toplant1 } \\
\text { Tarihi }\end{array}$ & Üye Sayısı & Katılımcı Sayısı & $\begin{array}{c}\text { Devamsız Üye Sayısı } \\
\text { [mazeretsiz + mazeretli] }\end{array}$ \\
\hline 1 & 18.12.2008 & 97 & $*$ & ${ }^{*}$ \\
\hline 2 & 22.01 .2009 & 97 & $*$ & $*$ \\
\hline 3 & 11.06 .2009 & 97 & * & * \\
\hline 4 & 04.11 .2009 & 97 & * & * \\
\hline 5 & 08.02 .2010 & 97 & * & $*$ \\
\hline 6 & 12.07.2010 & 97 & $(74)$ & $(23)$ \\
\hline 7 & 13.09.2010 & 97 & $(87)$ & $(10)$ \\
\hline 8 & 06.12 .2010 & 97 & $*$ & $*$ \\
\hline 9 & 02.02 .2011 & 97 & 58 & $39(22)$ \\
\hline 10 & 05.05 .2011 & 97 & $(69)$ & $(28)$ \\
\hline 11 & 07.09 .2011 & 97 & $(77)$ & $(20)$ \\
\hline 12 & 08.12 .2011 & 97 & 57 & $25(15)$ \\
\hline 13 & 15.03.2012 & 97 & $(87)$ & $(10)$ \\
\hline 14 & 07.06 .2012 & 97 & $(78)$ & $(19)$ \\
\hline 15 & 20.09 .2012 & 97 & $(70)$ & $(27)$ \\
\hline 16 & 25.06 .2013 & 97 & $(79)$ & (18) \\
\hline 17 & 03.07.2013 & 97 & 82 & $6(9)$ \\
\hline 18 & 26.09 .2013 & 97 & 78 & $5(14)$ \\
\hline 19 & 26.12 .2013 & 97 & 72 & $8(17)$ \\
\hline 20 & 10.04 .2014 & 97 & 73 & $8(16)$ \\
\hline
\end{tabular}

*Toplantı tutanaklarında belirtilmemiştir.

Kaynak: Toplantı tutanaklarından yararlanılarak yazar tarafından geliştirilmiştir. 


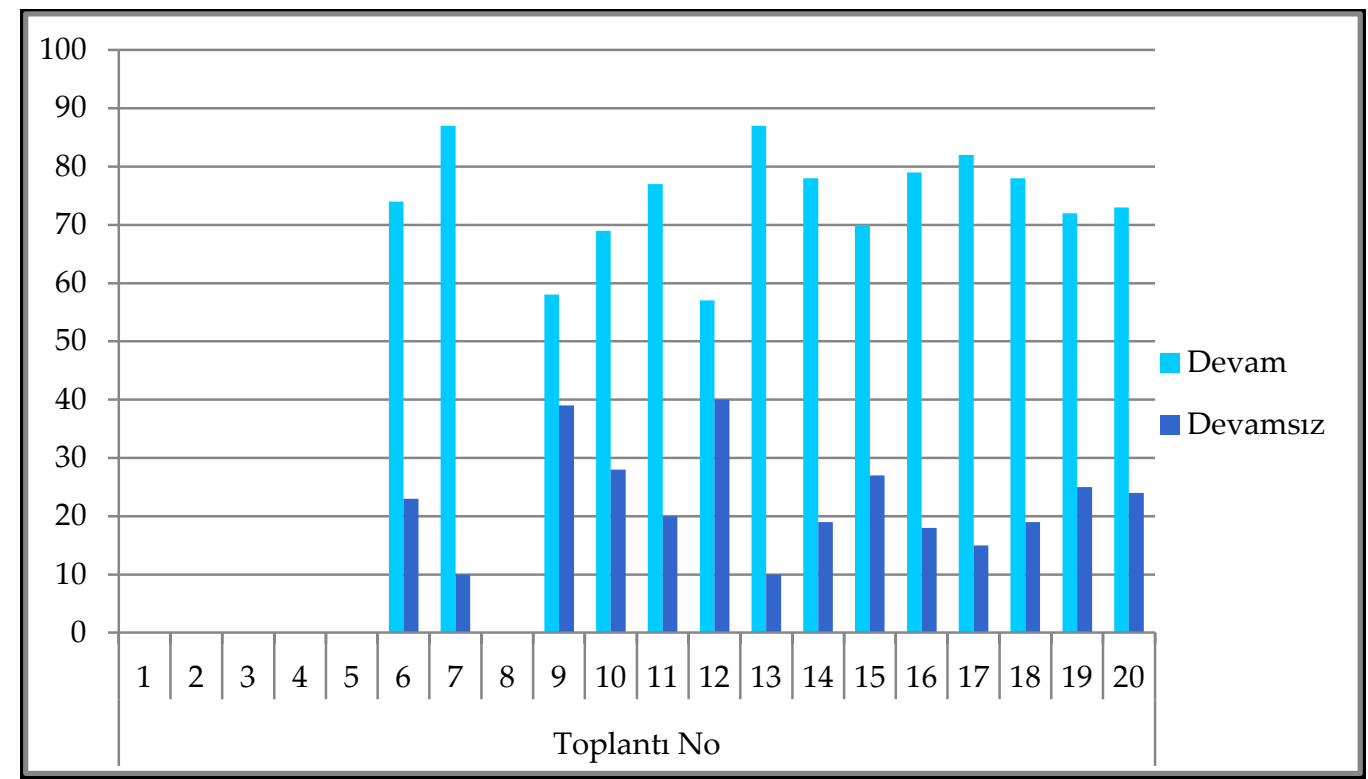

Grafik 1. Kalkınma Kurulu Üyelerinin Toplantılara Katılım Durumu (2008-2014)

Üyelerin ifadelerinden, Tablo 7'den ve Grafik 1'den de anlaşılacağı üzere kurul toplantılarına katılım konusunda önemli bir devamsızlık sorunu vardır. Tablo 7’ye göre ilk 5 toplantı ile 8. toplantının tutanaklarında, bu soruna ilişkin bir veriye yer verilmemiştir. Diğer toplantıların tutanaklarında ise, genellikle mazeretli devamsız üyeler belirtilmiştir. Tutanaklardan derlenen verilere göre, üyelerin yaklaşık \% $22^{25}$ oranında devamsızlık yaptığı tespit edilmiştir. En çok devamsızlık sırasıyla 9. (39 kişi), 10. (28 kişi), 15. (27 kişi) ve 12. (25 kişi) toplantıda yapılmıştır. Bu bulgular, KK'da toplantılara katılım bakımından da yönetişimin (aktif boyutu) kısmen sağlandığı şeklinde yorumlanabilir.

\subsection{Kalkınma Kurulu'nda Oluşturulan Çalışma Grubu ve Komite Sayısı}

BKA'larda yönetişimi güçlendirecek unsurlardan biri, KK bünyesinde katılımcı ve müzakereci bir yapıda çalışma grupları ve komiteler oluşturulmasıdır (Özer, 2009: 310). KK'da uygulanan yönetişim düzeyi, belli bir konuda araştırma yapmak üzere oluşturulan bu ekiplerin sayısına göre de belirlenebilir.

IZZKA KK, etkinliğini artırmak için çalışma grupları ve komiteler kurmuştur. Bu ekipler, kurula ve ajansa yönelik incelemeler yapmışlar, öneriler geliştirmişler ve bunları kurula sunmuşlar. Bunlara ilişkin veriler Tablo 8'de sunulmuştur.

$25 \% 22$ oranı, toplam devamsız üye sayısının toplantı sayısına bölünmesiyle (307/14) hesaplanmıştır. 
Tablo 8. İZKA Kalkınma Kurulu'nda Oluşturulan Çalışma Grupları ve Çalışma Komiteleri

\begin{tabular}{|c|c|c|}
\hline & Toplantı No & Toplantının İçeriği \\
\hline \multirow{3}{*}{ 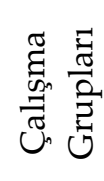 } & 4 & Çalışma grupları oluşturulmasına karar verilmiştir. \\
\hline & 5 & Çalışma grupları oluşturulmuştur. \\
\hline & $6,12,13,15$ & Çalışma grupları, faaliyetlerini kurula anlatmışlar. \\
\hline \multirow{3}{*}{ 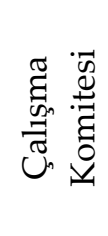 } & 10 & $\begin{array}{l}\text { KK'nın daha etkin çalışmasını araştırmak üzere Çalışma } \\
\text { Komitesi kurulmuştur. }\end{array}$ \\
\hline & 11 & Çalışma Komitesi, önerilerini kurula sunmuştur. \\
\hline & 12 & $\begin{array}{l}\text { Çalışma Komitesi, ajansın daha etkin çalışması için "mevzuat } \\
\text { değişikliği"ne yönelik önerilerini kurula sunmuştur. }\end{array}$ \\
\hline
\end{tabular}

Kaynak: Yazar tarafından geliştirilmiştir.

Tablo 8'e göre, KK'nın etkinliğini artırmak için 4. toplantıda verilen kararla 5. toplantıda çalışma grupları oluşturulmuştur. Bunlar, İleri Teknolojiye Dayalı Sanayiler Çalışma Grubu (7 üye); Yenilenebilir Enerji Çalışma Grubu (7 üye); Turizm Çalışma Grubu (14 üye); Lojistik ve Ulaşım Çalışma Grubu (6 üye); Tarım ve Tarıma Dayalı Sanayi Çalışma Grubu (9 üye); Tanıtım Çalışma Grubu (16 üye) ve Kümelenme Çalışma Grubu (5 üye). Çalışma gruplarında toplam 64 üye yer almıştır. Başka bir toplantıda ise, Z. Toprak'ın önerisi ile Bütünleşik Kıyı Yönetimi Çalışma Grubu kurulmuştur. Böylece çalışma grubu sayısı sekiz olmuştur.

Çalışma grupları, KK'da yönetişimin gelişmesine katkı sağlamışlar. Kurulun ve ajansın yerel kalkınmaya yönelik etkinliğini artırma konusunda tespitlerini ve önerilerini, 6., 12., 13. ve 15. toplantıda kurula sunmuşlar.

KK, etkinliğini artırmaya yönelik araştırma yapmak için de 10. toplantıda 20 üyeli bir Çalışma Komitesi kurmuştur. Komitenin 11. toplantıda kurula sunduğu önerilerden yönetişim ile ilgili olanlar şunlardır (Çelik, 2017b: 70-71):

- Kurul, merkez ve çevre ilçelerdeki kamu-özel-sivil kesim arasında adil bir şekilde oluşturulmalıdır.

- Kurul toplantılarına katılımı artırmak için vali ve belediye başkanları, yerlerine bir kişi görevlendirmelidir.

- Toplantılara devam konusunda mevcut kurallar uygulanmalıdır.

- Bölgenin öncelikleri, sektörlere ayrılan bütçe payları ve ajansın faaliyetleri, kurulda kararlaştırılmalıdır.

- Kurul ("meclis"), yılda dört defa toplanmalıdır.

Çalışma Komitesi'nin önerileri, kurulda oybirliğiyle kabul edilmiştir.

Komite, BKA'larla ilgili mevzuat değişikliğine ${ }^{26}$ dair de öneriler geliştirmiştir. Bunlardan yönetişimle ilgili olanlar da şunlardır (Çelik, 2017b: 72):

\footnotetext{
${ }^{26}$ KK Başkanı toplantıda, Devlet Planlama Teşkilatı'nın 5449 sayılı BKA Kanunu ile ilgili değişiklik taleplerini ve önerilerini istemesi üzerine Çalışma Komitesi'nin raporunun gönderildiğini belirtmiştir.
} 
- "Meclis"ten Yönetim Kurulu'na, “atanmış"lardan bir fazla üye seçilmelidir.

- Bölgenin öncelikleri ve verilecek destek miktarı, kurulun görüşü alınarak belirlenmelidir.

- Ajansın, yönetişim ve bölgesel kalkınmaya yönelik işlevselliğini ortadan kaldıran veya engelleyen yasal hükümler yeniden düzenlenmelidir.

- Yasada, Yönetim Kurulu'nun ajansın "hiyerarşi üstü" ve "vesayet makamı” gibi davranmasına yol açan hükümler kaldırılmalıdır.

- Vali ve belediye başkanları, "müzakere iklimi"ni değerlendirebilmek için kurul toplantılarına sürekli katılmalıdır.

Çalışma Komitesi'nin yönetişimle ilgili önerilerinin, literatürde BKA'lara yöneltilen eleştirilerle de örtüştüğü gözlenmiştir. Yukarıdaki önerilerde, kurulun oluşumu, üyelerin katılımı ve kararlarının bağlayıcılığı gibi hususlar vurgulanmıştır.

Kısaca KK, etkinliğini artırmak üzere çalışma grupları ve komiteler kurmuştur. $\mathrm{Bu}$ durum, yönetişimin aktif bir şekilde gerçekleşmesine katkıda bulunmuştur.

\section{SONUÇ}

Dünyada 1930'lardan itibaren BKA'lar kurulmuştur. BKA'lar, merkezi ve/veya yerel aktörlerin işbirliğinde yönetişim yaklaşımına göre kurulmuş ve yönetilmiştir. Yönetişim yaklaşımı, başlıca iki unsura dayanmaktadır. İlki, yetki ve sorumlulukların aktörler arasında paylaşılmasıdır; yani katılımcılıktır. İkincisi, eşitler arası ilişkilere dayalı heterarşik bir yapının kurulmasıdır.

Türkiye'de 2006 yılından itibaren kurulan BKA'lardan biri, İZKA'dır. İZKA, Kalkınma Kurulu, Yönetim Kurulu ve Yatırım Destek Ofisi şeklinde örgütlenmiştir. Bunlardan KK, 100 tane temsilciden oluşmuştur. KK'nın oluşum ve işleyiş sürecinde uygulanan yönetişim yaklaşımı, bu araştırmada geliştirilen kriterlere (Bkz. Tablo 5) göre belirlenmeye çalışılmıştır. Analiz sonucunda yapılan başlıca tespitler şunlardır:

- KK, İzmir'deki kamu, özel ve sivil kesimlerin temsilcileri ile yönetişim (pasif boyutu) temelinde oluşturulmuştur (Bkz. Tablo 6). Ancak bu kesimlerin kuruldaki temsil gücünde bir denge sağlanamamıştır. Örneğin KK'da özel kesim içinde sermaye sınıfı, emek sınıfına nispeten önemli bir paya (\% 97) sahiptir.

- Üyelerin kurul toplantılarına katılımı konusunda önemli (yaklaşık \% 22) bir devamsızlık sorunu (yönetişimin aktif boyutu) vardır (Bkz. Tablo 7 ve Grafik 1). Bu durum, üyeler ve DDK tarafından da ifade edilmiştir.

- KK, etkinliğini artırmak için çalışma grupları ve komiteler kurmuştur (Bkz. Tablo 8). Bu gelişme, kurulda uygulanan yönetişim düzeyini artırmıştır.

Yukarıdaki tespitlerden hareketle İZKA KK'nın oluşum ve işleyiş sürecinde, üyelerin toplumsal kesimler itibariyle dağılımı ve toplantılara katılımı bakımından yönetişim yaklaşımının kısmen uygulandığına kanaat getirilmiştir. Buna göre KK'nın yönetişim bakımından işlevselliğini artırmak için şu hususlar önerilebilir:

- KK üyelerinin kamu-özel-sivil kesimler itibariyle dağılımı yapılırken, bu kesimlerin bölgenin sosyo-ekonomik yapısındaki payı da dikkate alınmalıdır. 
Bu durumda muhtemelen tarım sektörü temsilcisinin sayısı artacaktır. Özel kesim içinde emek sınıfının temsil oranı artırılmalıdır. Sivil kesim içinde ise, dezavantajlı kesimlere de yer verilmelidir.

- Üyelerin toplantılara katılımını sağlayacak tedbirler geliştirilmelidir. $\mathrm{Bu}$ konuda, toplantılara belli bir süre katılmayan üyelerin üyeliklerinin düşürülmesi; katılımcı üyelere huzur hakkı verilmesi gibi tedbirler önerilebilir.

\section{KAYNAKÇA}

Akpınar, R. (2010). Türkiye'de Kalkınma Ajanslarınca Hazırlanan Bölge Planlarına Dair Bir Kritik: İZKA'nın İzmir Bölge Planı (2010-2013) Örneği, Dokuz Eylül Üniversitesi Sosyal Bilimler Enstitüsü Dergisi, 12 (4): 7-18.

Akpınar, R. (2017). Yerel Yönetişimin Yeni Bir Kurumsal Aracı Olarak Kalkınma Kurulları: İzmir Kalkınma Kurulunda Nitel Bir Araştırma, Pamukkale Üniversitesi Sosyal Bilimler Enstitüsü Dergisi, 28: 297-310.

Allen, G. (2002). Regional Development Agencies (RDAs), 48 p.

Arslan, F. (2016). Yönetişimsiz Yönetimler: Türkiye'de Kalkınma Ajansları, Çă̆daş Yerel Yönetimler, 25 (2): 29-52.

Asheim, B. (1995). Industrial Districts as 'Learning Regions'. A Condition for Prosperity?, http://www.nifu.no/files/2012/11/STEPrapport3-1995.pdf, 24 p.

Aydoğdu, Ç. (2010). Kalkınma Ajansları ve Toplumsal Sermaye İlişkilerinde Stratejik Yaklaşım. (Basılmamış Yüksek Lisans Tezi). İzmir: Dokuz Eylül Üniversitesi Sosyal Bilimler Enstitüsü.

Beer, A. P. and Maude, A. (2005). Governance and The Performance of Regional Development Agencies in Australia. in book Participation and Governance in Regional Development: Global Trends in An Australian Context, Publisher: Ashgate, Ed.: R.Eversole and J. Martin, 61-77.

Burak, M. B. (2011). Kalkınma Ajanslarının Bölge Planlama Sürecindeki Yeri, İzmir Kalkınma Ajansı 2010-2013 İzmir Bölge Planı Örneği. (Basılmamış Yüksek Lisans Tezi). İzmir: Dokuz Eylül Üniversitesi Fen Bilimleri Enstitüsü.

CEC (Commission Of The European Communities). (2001). European Governance: A White Paper, COM (2001) 428 final, Brussels, 35 p.

Çalt, G. (2005). Bölgeselleşme ve Avrupa Birliği'nin Bir Aracı Olarak Bölge Kalkınma Ajansları, http://www.zmo.org.tr/resimler/ekler/8df7b8e8d586a55_ek.pdf, 20 s.

Çelik, F. (2015). Bölgesel Kalkınma Ajanslarının Yeniliklere Katkıları: Teori, Deneyimler ve Türkiye Uygulamalarının Değerlendirilmesi. (Basılmamış Doktora Tezi). Kayseri: Erciyes Üniversitesi Sosyal Bilimler Enstitüsü.

Çelik, F. (2016). İzmir Kalkınma Ajansı (IZKA) Örneğinde Kalkınma Kurulu'nun Gündem Belirleme Faaliyetlerinin Değerlendirilmesi, Nevşehir Hacı Bektaş Veli Üniversitesi Sosyal Bilimler Enstitüsü Dergisi, 6 (2): 45-67.

Çelik, F. (2017a). Bölgesel Kalkınma Ajansı Deneyimlerinin Karşılaştırmalı Analizi: İngiltere ve Türkiye Örnekleri, Afyon Kocatepe Üniversitesi Sosyal Bilimler Enstitüsü Dergisi, 19 (2): 145-171. 
Çelik, F. (2017b). İzmir Kalkınma Ajansı (İZKA) Kalkınma Kurulu'nun Etkinliğini Artırma Girişimleri, Süleyman Demirel Ün. Sosyal Bilimler Ens. Dergisi, 27: 55-80.

Dall'Olio, R. (2006). Emilia-Romagna'da Bölgesel Kalkınma ve Yönetişim: Ervet Deneyimi, Bölgesel Kalkınma ve Yönetişim Sempozyumu, Ankara, 69-72.

DDK (Cumhurbaşkanlı̆̆ı Devlet Denetleme Kurulu). (2014). Türkiye'nin Kalkınma Ajansları Uygulamasının Değerlendirilmesi, $830 \mathrm{~s}$.

Dinler, Z. (2008). Bölgesel İktisat. Bursa: Ekin Yayını, 449 s.

Dulupçu, M. A. (2006). Bölgesel Politikalar Kopyalanabilir mi? Bölgeselleşme Karşısında Yeni Bölgeselcilik, 1. Bölgesel Kalkınma ve Yönetişim Sempozyumu, Ankara, 233-255.

Eldeniz, F. (2011). The Assessment Of Institutional Performance in Izmir Development Agency. (Basılmamış Yüksek Lisans Tezi). Ankara: Orta Doğu Teknik Üniversitesi Sosyal Bilimler Enstitüsü.

Eraydın, A. (2007). Politikalardan Süreç Tasarımına: Yeni Bölgesel Politikalar ve Yönetişim Modelleri, 2. Bölgesel Kalkınma ve Yönetişim Sempozyumu, İzmir, 5-23.

Ersayın, Z. (2012). Kamu Müdahalelerinde Katkısallığın Değerlendirilmesi: Çukurova ve İzmir Kalkınma Ajansları KOBİ Destekleri Örneği. (Basılmış Uzmanlık Tezi). Ankara Devlet Planlama Teşkilatı.

Ertugal, E. (2017). Challenges For Regional Governance in Turkey: The Role of Development Agencies (1), METU Journal of The Faculty of Architecture, 34 (2): 203-224.

EURADA. (1999). Creation, Development and Management of RDAs. Does it have to be so difficult?

http://www.eurada.org/files/RDA/Creation\%20development\%20and\%20management $\%$ 20of\%20RDA.pdf, 169 p.

Gibbs, D. and Jonas, A. (2001). Rescaling and Regional Governance: The English Regional Development Agencies and the Environment, Environment and Planning C: Government and Policy, 19: 269-288.

Grant, J. (2004). Gippsland's Regional Development Agencies: The Truumph of Tribalism Over Regionalism, Australasian Journal of Regional Studies, 10 (1): 49-75.

Günaydın, D. (2013a). Bölgesel Kalkınma Sürecinde Kümelenmeler: TR31 İzmir Bölgesi Örneği, International Anatolia Academik Online Journal, 1 (2): 11-47.

Günaydın, D. (2013b). Türkiye'de Bölgeler Arası Gelişmişlik Farkların Giderilmesinde Kalkınma Ajanslarının Yeri: İZKA Mali Destek Programları Örneği, Dokuz Eylül Üniversitesi Sosyal Bilimler Enstitüsü Dergisi, 15 (1): 73-101.

Gündoğdu, İ. (2009). Sermayenin Bölgesel Kalkınma Eğilim(ler)i: Kalkınma Ajansları Yasası Üzerine Tarihsel-Coğrafi Materyalist Bir İnceleme, Praksis, 19: 267-302.

Güney, R. ve Sat, N. (2016). Bölge Planlamada Katılım: İzmir ve Batı Karadeniz Kalkınma Ajansları Üzerine Bir İrdeleme. Planlama, 26 (2): 101-116.

Halkier, H. (2000). Regional Policy An Inter-Organisational Approach, Regional and Industrial Policy Research Paper Number 37, European Policies Research Centre University of Strathclyde, UK, 53 p. 
Halkier, H. (2006). Bölgesel Kalkınma Ajansları ve Çok Düzlemli Yönetişim: Avrupa Perspektifi, 1. Bölgesel Kalkınma ve Yönetişim Sempozyumu, Ankara, 17-28.

Halkier, H. (2010). Regional Policiy in European Regions: A Survey of Regional Development Agency Policies and Their Knowledge Implications, $50 \mathrm{p}$.

Halkier, H. (2011). Regional Development Agencies: European Trends and Experiences. In C. C. Aktan (Ed.), The Proceedings of 1st International Conference on Regional Development. Malatya, Turkey: Firat Development Agency, 1-10.

Harding, R. (2006). İngiltere ve Romanya'da Bölgesel Kalkınma Ajansı Deneyimleri, 1. Bölgesel Kalkınma ve Yönetişim Sempozyumu, Ankara, 137-160.

Haşar, E. Ç. ve İneler, F. M. (2011). İzmir Kümelenme Stratejisi Deneyimi ve Kümelenmenin Yönetimi, 5. Bölgesel Kalkınma ve Yönetişim Sempozyumu, Ankara, 253-272.

Helvacıoğlu Kuyucu, A. ve Tektaş, A. (2010). Bölgesel Kalkınma Ajansları: Etkin Fon Kullanımı ve Çok Düzeyli Yönetişime Geçiş, içinde Akgül, B. ve Uzay, N.(Ed) (2010), Türkiye'de Bölgesel Kalkınmanın Yeni Örgütleri, Kalkınma Ajansları, Bursa: Ekin Yayınevi, 535-552.

İçen, A. (2012). Türkiye'deki Bölgesel Kalkınma Ajanslarının Kırsal Kalkınmadaki Rolü: İzmir Kalkınma Ajansı Örneği. (Basılmamış Yüksek Lisans Tezi). Yalova: Yalova Üniversitesi Sosyal Bilimler Enstitüsü.

İKA (İzmir Kalkınma Ajansı). Kalkınma Kurulu Toplantı Tutanakları (18.12.2008-10.04.2014).

IZKA. Kalkınma Kurulu Toplantı Sonuç Bildirgeleri (18.12.2008-10.04.2014).

IZKA. Kalkınma Kurulu Toplantısı Karar Özetleri (07.09.2011, 08.12.2011, 15.03.2012, 07.06.2012, 20.09.2012, 26.09.2013, 26.12.2013, 10.04.2014).

İKA. İzmir Kümelenme Stratejisi 2013-2018, $36 \mathrm{s.}$

IZZKA. (2011). İZKA Etki Analizi Araştırması, $117 \mathrm{~s}$.

IZKA. (2012). İzmir Bölgesel Yenilik Stratejisi, $110 \mathrm{~s}$.

Karakılçık, Y. ve Sarıgül, C. E. (2010). Bir ‘Ekonomik Yönetişim Modeli' Olarak Bölge Kalkınma Ajansları (BKA) Uygulaması: Üniter Yapının ve Sosyal Devletin Tasfiyesi mi Tesviyesi mi? http://web.inonu.edu.tr/ ozal.congress/pdf/28.pdf, 384-408.

Karasu, K. (2005). İngiltere'de Bölge Kalkınma Ajansları, Turan, M. (Ed.), Bölge Kalkınma Ajansları Nedir? Ne Değildir?, Paragraf Yay., Ankara, 197-238.

Karasu, K. (2009). Yerelleşme Söylemi ve Bölge Kalkınma Ajansları, Memleket Siyaset Yönetim, 4 (11): 1-43.

Karasu, K. (2015). Kalkınma Ajansları: 'Modelimi Kaybettim. Hükümsüzdür' Ölçek Siyasetinin Yerelliği, Ankara Üniversitesi SBF Dergisi, 70 (2): 273-316.

Kayasü, S., Pınarcıoğlu, M., Yaşar, S. S. ve Dere, S. (2003). Yerel/Bölgesel Ekonomik Kalkınma ve Rekabet Gücünün Artırılmasi: Bölgesel Kalkınma Ajansları, İstanbul: İTO Yayını, 148 s.

Kayasü, S. and Eldeniz, F. (2013). Institutional Performance of Izmir Development Agency (1), METU Journal of The Faculty of Architecture, 30 (1): 57-78.

Koçak, S. Y. ve Karkın, N. (2010). Kalkınma Ajanslarının Çoklu Paydaş Kuramı Çerçevesinde Analizi, Akgül, B. ve Uzay, N. (Ed) (2010) içinde, 591-607. 
Lagendijk, A., Kayasü, S. and Yasar, S. (2009). The Role of Regional Development Agencies in Turkey: From Implementing EU Directives To Supporting Regional Business Communities?, European Urban and Regional Studies, 16: 383-396.

Maccani, P. (2007). The Role of a Regional Development Agency in The Improvement of Regional Territorial Policies. Italy-Turkey Bilateral Cooperation Project Izmir 22nd- 24th May http://www.dps.tesoro.it/cd_cooperazione_bilaterale/docs/3.Development_Tool223s/1.B est_practices/1.role_RDA_improv_reg_territ_pol_maccani.pdf, 31 p.

Marzocchi, C. (2009). The Evolution of An Innovation Policy in A Local System of Production. The Case of The Regional Programme for Industrial Research, Innovation and Technology Transfer. (PhD thesis), Università degli studi di Ferrara, 145 p.

Morris, M. (2010). Multi-Sectoral Collaboration and Economic Development: Lessons from England's Regional Development Agencies, https://www.unbc.ca/sites/default/files/assets/community_development_institute/publi cations/marleen_morris_final.pdf, 51 p.

Müftüoğlu, B. G. (2006). Küresel Rekabetin Cazibe Merkezleri: Yerel/ Bölgesel Dinamikler, içinde Arı, F. Aylan (Ed.), Bölgesel Kalkınma Politikalar ve Yeni Dinamikler, İstanbul: Derin Yayınevi, 117-148.

Müftüoğlu, B. G. (2012). Türkiye'de Yeni Emek Denetim ve Kontrol Alanı: Kalkınma Ajansları, Çalışma ve Toplum, 33 (2): 95-116.

Özdemir, S. Y. ve İneler, F. M. (2009). Kümelenme, Bölgesel Kalkınma ve Kalkınma Ajansları, http://www.izmiryenilik.org/phocadownloadpap/kumelenme_izka_bolgebilimi_ozdem ir_ineler.pdf, $13 \mathrm{~s}$.

Özer, Y. E. (2009). Bölgesel Kalkınma Ajanslarının Yapılanması ve İşlevselliği: İzmir ve Çukurova Örnekleri. (Basılmamış Doktora Tezi). İzmir: Dokuz Eylül Üniversitesi Sosyal Bilimler Enstitüsü.

Özışık, F. U. (2012). Küreselleşme-Yerelleşme Sürecinde Kentsel Yönetişim: Kalkınma Ajansları ve İzmir Örneği, Kent Akademisi, 5 (4): 129-145.

Özışık, F. U. (2015). Kent-Bölge Kavramı Işığında Türkiye'de Büyükşehir Belediye Sisteminde Değişim ve Kalkınma Ajansları: Yerel Ölçekte Mekânın ve Yönetişimin Yeniden Tanımlanması, Akademik Incelemeler Der., 10 (1): 313-342.

Özkan, H., Kırdaş, E. K. ve Koç, T. (2012). Yoksulluk Sorununu Görmeyen Bir Kalkınma Modeli Olarak Yönetişimci Kalkınma: Adana Örneği, Ankara Üniversitesi Siyasal Bilgiler Fakültesi Dergisi, 67 (4): 89-124.

Pearce, G. and Ayres, S. (2009). Governance in the English Regions: The Role of the Regional Development Agencies, Urban Studies, 46 (3): 537-557.

Roberts, P. (1999). The New Regional Agenda in the UK: Changing Roles, Structures and Functions of Regional Development Agencies. Regional Science Association International-British and Irish Section 39th European Congress: Dublin, 17 p.

Roberts, P. W., and Lloyd, M. G. (1999). Institutional Aspects of Regional Planning, Management, and Development: Models and Lessons from the English Experience, Environment and Planning B: Planning and Design, 26 (4): 517-531. 
Roberts, P. W., and Lloyd, M. G. (2000). Regional Development Agencies in England: New Strategic Regional Planning Issues?, Regional Studies, 34 (1): 75-79.

Şimşek, A. (2013). Kalkınma Ajanslarının Performans Ölçümü. (Uzmanlık Tezi). Ankara: Kalkınma Bakanlığı, $159 \mathrm{~s}$.

Yıldırım, A. ve Şimşek, H. (2013). Sosyal Bilimlerde Nitel Araştırma Yöntemleri. Ankara: Seçkin Yayınevi, $448 \mathrm{~s}$.

Young-Hyman, T. (2008). The Potential for Effective Regional Development Agencies in Turkey: A Comparative Analysis, Regional and Federal Studies, 18 (4): 375-402.

5449 Sayılı Kalkınma Ajanslarının Kuruluşu, Koordinasyonu ve Görevleri Hakkında Kanun (8.2.2006 Tarih ve 26074 Sayılı Resmi Gazete). 